\title{
Hubungan Persepsi Penyakit (Illness Perception) dengan Kontrol Gejala Asma pada Pasien Rawat Jalan
}

\author{
Amelia Lorensia, Rika Yulia dan Ika Sari Wahyuningtyas
}

Departemen Farmasi Klinis-Komunitas, Fakultas Farmasi, Universitas Surabaya

Korespondensi: Amelia Lorensia

Email: amelia.lorensia@gmail.com

\begin{abstract}
ABSTRAK: Prevalensi asma cukup tinggi di Indonesia. Terapi asma memerlukan self-management yang baik dari pasien yang meliputi persepsi dan pemahaman terhadap penyakit. Persepsi penyakit (illness perception) dapat mempengaruhi kepatuhan pasien dalam pengobatan yang dapat menyebabkan tujuan terapi tidak tercapai. Penelitian ini bertujuan mengetahui seberapa besar hubungan persepsi penyakit dengan hasil outcome klinis berupa kontrol gejala asma. Oleh karena itu, dilakukan penelitian hubungan persepsi sakit (illness perception) dan kontrol asma. Penelitian ini merupakan non eksperimental melalui pengisian kuesioner oleh responden. Responden dalam penelitian ini adalah pasien asma yang menjalani rawat jalan di suatu apotek swasta di Surabaya. Kuesioner yang digunakan dalam penelitian ini adalah Asthma Control Test (ACT) dan Illness Perception Questionnaire (IPQ). Besar sampel penelitian adalah 20 orang yang seluruhnya memiliki control asma yang baik. Hasil penelitian ini menunjukkan bahwa $65 \%$ responden asmanya terkontrol dengan baik; 40\% responden merasa asmanya tidak berpengaruh terhadap aktifitas; 50\% responden merasa obat-obatan yang digunakan membantu serangan asma. Ada hubungan antara kontrol asma dan persepsi penyakit dalam aspek personal control dan identity. Tetapi, tidak terdapat hubungan antara kontrol asma dan persepsi penyakit dalam aspek consequences, timeline, treatment control, concern, dan emotional response.
\end{abstract}

Kata kunci: asma kronis; kontrol asma; persepsi penyakit

\begin{abstract}
The prevalence of asthma is quite high in Indonesia. Asthma therapy requires good selfmanagement of patients that includes the perception and understanding of the disease. Illness perception can affect patient adherence to the treatment leading to therapy goals are not achieved. This study aims to find out how much the relationship between perception of disease with clinical outcome results in the form of control of asthma symptoms. Therefore, the perception of pain research relationship (illness perception) and asthma control. This is a non-experimental study through questionnaires by respondents. Respondents in this study were asthma patients undergoing outpatient treatment at a private pharmacy in Surabaya. The questionnaire used in this study is the Asthma Control Test (ACT) and the Illness Perception Questionnaire (IPQ). The results of this study showed that 65\% of respondent asthma is well controlled; 40\% of respondents felt their asthma did not affect the activity; 50\% of respondents feel drugs are used to help an asthma attack. There was a relationship between asthma control and perception of disease in the aspect of personal control and identity. However, there is no relationship between asthma control and perception of disease in the aspect of consequences, timeline, treatment control, concern, and emotional response.
\end{abstract}

Keywords: chronic asthma; asthma control; illness perception 


\section{Pendahuluan}

Hasil survey tahun 1996, penyakit-penyakit yang dapat menyebabkan sesak napas seperti bronkhitis, emfisema, dan asma merupakan penyebab kematian ke-7 di Indonesia, sedangkan survey tahun 2005 mencatat 225.000 orang meninggal karena asma dan prevalensi asma di Indonesia untuk daerah pedesaan 4,3\% dan perkotaan 6,5\% [1]. Asma merupakan gangguan inflamasi kronik pada saluran nafas yang melibatkan banyak sel dan elemen selular di dalamnya, sehingga menyebabkan gejala berulang wheezing (mengi), sulit bernafas, rasa sesak pada dada dan batuk. Tujuan pengobatan asma adalah mencapai dan mempertahankan kontrol asma dalam waktu yang lama dengan efek dan biaya pengobatan yang sesuai [2].Penatalaksanaan asma merupakan pengobatan jangka panjang yang akan sangat dipengaruhi oleh self-management pasien itu sendiri, terutama dari faktor kepatuhan terhadap pengobatan.Ketidakpatuhan terhadap terapi asma dapat menyebabkan gejala asma menjadi tidak terkontrol sepanjang hari, keterbatasan aktivitas, bahkan dapat membutuhkan penanganan di unit gawat darurat di rumah sakit [3-7].

Self-managemet pasien akan sangat dipengaruhi oleh illness perception (persepsi penyakit) karena persepsi pada diri masing-masing individu mengakibatkan respon individu yang berbeda antara satu individu dengan individu yang lain. Oleh karena itu, selain faktor kesesuaian obat yang digunakan kita juga harus memperhatikan persepsi dari dalam diri pasien itu sendiri terhadap penyakitnya [1].

Penelitian sebelumnya yang dilakukan oleh Lorensia dan Lisiska (2011) [8], terhadap 20 pasien asma kronis rawat jalan di poli paru suatu rumah sakit swasta di Surabaya, menemukan bahwa gejala penyakit yang sebagian besar dialami pasien adalah sesak nafas, suara mengi, lelah, dan sulit tidur; dampak penyakit asma adalah mempengaruhi aktivitas; penyebab tertinggi asma adalah keturunan, polusi lingkungan, dan pola/kebiasaan makan; hanya sebagian kecil pasien yang menge- tahui penyakit asma berlangsung selamanya; dan pasien yakin bahwa pengobatan yang selama ini digunakan dapat membantu mengontrol penyakit asmanya. Persepsi pasien mengenai identity, cause of illness, dan cure or control sudah tepat, sedangkan yang mengenai consequences dan timeline masih kurang. Pengukuran terhadap illness perception dapat digambarkan dengan lima dimensi dalam cognitive representation of illness antara lain: (1) Identify (label pasien yang digunakan untuk menggambarkan illness dan gejala yang mereka alami sebagai bagian dari penyakit (disease)); (2) Consequences (efek yang diharapkan dan outcomes dari illness); (3) Cause (ide personal mengenai penyebab dari penyakit); (4) Timeline (berapa lama pasien mempercayai bahwa penyakitnya akan berlangsung); dan (5) Cure atau Control (menjelaskan apa yang dipercayai pasien bahwa mereka dapat pulih atau sembuh dari penyakitnya) [9-11].

Penelitian serupa diperlukan untuk mengetahui profil persepsi pasien asma rawat jalan (asma kronis) dengan latar belakang tempat berbeda, yaitu di area komunitas (apotek) karena pasien di area komunitas cenderung berobat pada dokter-dokter yang berbeda. Hal ini yang membedakan dengan kondisi pasien asma di rawat jalan di rumah sakit yang cenderung berasal dari dokter yang sama.

\section{Metode}

Penelitian ini merupakan penelitian cross-sectional yang merupakan penelitian non-eksperimental. Variabel penelitian ini adalah (1.) illness perception yang dinilai dengan kuesioner IPQ dan (2.) kontrol asma yang dinilai dengan kuesioner ACT.

Sampel penelitian ini adalah pasien yang sedang menjalani rawat jalan di suatu apotek di Surabaya. Instrumen untuk pengambilan data berupa kuesioner yang telah diuji reliabilitasnya. Teknik pengambilan sampel yang digunakan adalah nonprobability sampling yaitu purposive 
sampling sesuai dengan kriteria inklusi dan kriteria eksklusi.

Penelitian ini merupakan penelitian cross-sectional yang merupakan penelitian non-eksperimetal. Variabel penelitian ini adalah: (1) illness perception yang dinilai dengan kuensioner IPQ dan (2) control asma yang dinilai dengan kuesioner ACT. Sampel penelitian ini adalah pasien yang sedang menjalani rawat jalan di suatu apotek di Surabaya. Instrumen untuk pengambilan data berupa kuesioner yang telah diuji reliabilitasnya. Teknik pengambilan sampel yang digunakan adalah nonprobability sampling yaitu purposive sampling sesuai dengan kriteria inklusi dan kriteria eksklusi.

Perhitungan perkiraan jumlah sampel penelitian dengan persamaan perhitungan jumlah sampel pada penelitian cross-sectional [12] yaitu:

$$
\mathrm{n}=\frac{\mathrm{Z}_{1-\alpha, 2}^{2} \mathrm{P}(1-\mathrm{P})}{\mathrm{d}^{2}}
$$

dimana,

$\mathrm{n} \quad=$ jumlah sampel minimal yang diperlukan

$\mathrm{d}=$ limit dari error atau presisi absolut (25\%)

$\mathrm{Z}_{1-\alpha 2}=$ nilai $\mathrm{Z}$ tabel 1,96 (tingkat kepercayaan 95\%)

$\mathrm{p}=$ proporsi pasien asma $(\mathrm{p}=0,5)$

Jadi estimasi ukuran sampel minimum dalam penelitian ini adalah 18 pasien asma yang memenuhi kriteria inklusi dan eksklusi.

Kuesioner tersebut terbagi menjadi dua kelompok, yaitu Asthma Control Test (ACT) yang digunakan untuk mendapatkan nilai tingkat kontrol asma pasien dan Illness Perception Questionnaire (IPQ) yang digunakan untuk mendapatkan informasi mengenai persepsi pasien mengenai kondisi sakitnya, yang dibagi menjadi 8 aspek yaitu consequence, personal control, treatment control, identity, concern, understanding, timeline, dan emotional response. Dari data tingkat kontrol asma dan aspek dalam persepsi sakit maka dilihat hubungannya dengan menggunakan analisis Kruskal-Wallis.

\section{Hasil dan pembahasan}

\subsection{Karakteristik sampel penelitian (responden)}

Sebagian besar pasien yang datang ke apotek berjenis kelamin pria (55\%), usia 26-45 tahun (55\%), pendidikan SMA (50\%), lama sakit 1-15 tahun (40\%), tanpa riwayat penyakit dahulu (70\%), riwayat keluarga asma (45\%), tanpa riwayat alergi (90\%), dan yang terbiasa menggunakan obat golongan metilsanthin (35\%). Stage pengobatan penyakit asma ditentukan berdasarkan pengobatan rawat jalan yang diterima pasien saat diwawancara oleh peneliti, berdasarkan Global Initiative for Asthma tahun 2015 [2] (Tabel 1).

\subsection{Distribusi frekuensi analisis data uji tingkat kontrol asma}

Dari penelitian ini dapat dilihat bahwa sebagian besar responden memiliki kontrol asma yang baik (65\%) (Tabel 2).

\subsection{Distribusi frekuensi analisis data persepsi penyakit (illness perception)}

Gambaran jawaban responden terhadap pertanyaan kuesioner illness perception dapat dilihat pada Tabel 3 dan tergambar bahwa sebagian besar responden merasa bahwa asma tidak mempengaruhi aktifitas sehari-harinya. Namun sebagian besar responden ragu-ragu dalam menjawab berapa lama seseorang menderita asma dan menilai frekuensi penyakitnya. Responden merasa pengobatan yang dijalaninya telah membantunya, dengan kemunculan gejala asma sebagian besar berkisar antara 1-2x/minggu. Asma yang dialami tidak membuat sebagian besar responden terpengaruh emosinya, walaupun menimbulkan kekuatiran tersendiri.

Pendapat responden terhadap penyebab asma sebagian besar setuju bahwa genetik ( 9 orang), pola makan (12 orang), debu (12 orang), polusi lingkungan (14 orang), perilaku gaya hidup (12 orang), udara dingin (14 orang), aktivitas fisik (13 orang), terlalu banyak pekerjaan (15 orang), rasa emosional (9 orang), konsumsi alkohol 6 orang), merokok 11 (orang), kekebalan tubuh (16 orang) (Tabel 4). Ketika responden diminta untuk mengurutkan pilihannya, pilihan pertama terbanyak 
Tabel 1. Karakteristik responden

\begin{tabular}{|c|c|c|c|}
\hline \multirow{2}{*}{ Karakteristik } & & \multicolumn{2}{|c|}{ Responden } \\
\hline & & Jumlah & $\begin{array}{l}\text { Persentase } \\
(\%)\end{array}$ \\
\hline \multirow[t]{2}{*}{ Jenis kelamin } & Wanita & 9 & 45 \\
\hline & Pria & 11 & 55 \\
\hline \multirow[t]{4}{*}{ Usia (tahun) } & $12-25$ & 3 & 15 \\
\hline & $26-45$ & 11 & 55 \\
\hline & $46-65$ & 5 & 25 \\
\hline & $>65$ & 1 & 5 \\
\hline \multirow[t]{5}{*}{ Pendidikan terakhir } & Sekolah dasar & 5 & 25 \\
\hline & Sekolah menengah pertama & 2 & 10 \\
\hline & Sekolah menengah atas & 10 & 50 \\
\hline & Perguruan tinggi & 3 & 15 \\
\hline & $1-15$ & 8 & 40 \\
\hline \multirow{3}{*}{ Lama sakit (tahun) } & $16-30$ & 7 & 35 \\
\hline & $31-45$ & 4 & 20 \\
\hline & $>45$ & 1 & 5 \\
\hline \multirow[t]{3}{*}{ Penyakit penyerta } & Tanpa riwayat & 14 & 70 \\
\hline & Riwayat asma & 5 & 25 \\
\hline & Tuberkulosis & 1 & 5 \\
\hline \multirow{4}{*}{$\begin{array}{l}\text { Tingkat keparahan asma kronis } \\
\text { [2] dan golongan obat yang } \\
\text { digunakan }\end{array}$} & Step 1 (beta-2 agonis kerja cepat) & 6 & 30 \\
\hline & Step 2 (metilsantin) & 7 & 35 \\
\hline & $\begin{array}{l}\text { Step } 2 \text { (metilsantin \& beta-2 agonis } \\
\text { kerja cepat) }\end{array}$ & 4 & 20 \\
\hline & Step 3 (metilsantin \& kortikosteroid) & 3 & 15 \\
\hline
\end{tabular}

Tabel 2. Profil tingkat kontrol gejala asma responden

\begin{tabular}{lll}
\hline Kategori & Jumlah & Persentase (\%) \\
\hline Terkontrol sangat baik $(\geq 20)$ & 2 & 10 \\
Terkontrol dengan baik $(16-19)$ & 13 & 65 \\
Tidak terkontrol $(<16)$ & 5 & 25 \\
\hline Total & 20 & 100 \\
\hline
\end{tabular}

adalah bahwa faktor genetik sebagai penyebab asma, kemudian pilihan kedua terbanyak adalah polusi, dan pilihan ketiga terbanyak adalah sistem imun tubuh (Tabel 5). Genetik merupakan faktor host yang dapat menyebabkan asma yang dapat memicu munculnya allergic asthma [1], sedangkan yang lainnya bukan merupakan penyebab terjadinya asma tetapi faktor-faktor yang dapat menyebabkan perburukan asma.

\subsection{Hubungan antara persepsi penyakit dan kontrol gejala asma}

Hubungan antara nilai kontrol asma dengan persepi sakit yang meliputi consequences, time- line, personal control, treatment control, identity, concern, emotional response, dan understanding diuji dengan metode Kruskal-Wallis karena ada beberapa data yang tidak terdistribusi normal. Pemilihan uji statistik ini didasarkan pada uji normalitas Kolmogorov-Smirnov.

Hasil uji hubungan antara setiap aspek dari illness perception dengan kontrol asma dapat dilihat pada Tabel 6. Hasil penelitian menunjukkan bahwa tidak ada hubungan antara illness perception pada aspek: consequences, timeline, treatment control, concern, emotional response, dan understanding dengan kontrol gejala asma. Namun ada hubungan antara illness perception pada 
Tabel 3. Distribusi frekuensi analisis data persepsi penyakit (illness perception)

\begin{tabular}{|c|c|c|c|c|}
\hline $\begin{array}{l}\text { Aspek dari illness } \\
\text { perception }\end{array}$ & $\begin{array}{l}\text { Pertanyaan dalam } \\
\text { illness perception }\end{array}$ & Kategori & Jumlah & $\begin{array}{l}\text { Persentase } \\
(\%)\end{array}$ \\
\hline \multirow[t]{4}{*}{ Consequences } & \multirow{4}{*}{$\begin{array}{l}\text { Pengaruh asma terhadap } \\
\text { aktifitas }\end{array}$} & Tidak mempengaruhi & 8 & 40 \\
\hline & & Sedikit mempengaruhi & 4 & 20 \\
\hline & & Cukup mempengaruhi & 6 & 30 \\
\hline & & Sangat mempengaruhi & 2 & 10 \\
\hline \multirow[t]{4}{*}{ Timeline } & \multirow{4}{*}{$\begin{array}{l}\text { Pendapat mengenai lama } \\
\text { dirinya akan menderita } \\
\text { asma }\end{array}$} & Selama beberapa bulan & 1 & 5 \\
\hline & & Selama beberapa tahun & 6 & 30 \\
\hline & & Ragu-ragu & 8 & 40 \\
\hline & & Selamanya & 5 & 25 \\
\hline \multirow[t]{4}{*}{ Personal control } & \multirow{4}{*}{$\begin{array}{l}\text { Pendapat mengenai } \\
\text { frekuensi penyakit } \\
\text { asmanya }\end{array}$} & Sedikit terkontrol & 6 & 30 \\
\hline & & Ragu-ragu & 7 & 35 \\
\hline & & Terkontrol & 5 & 25 \\
\hline & & Terkontrol sempurna & 2 & 10 \\
\hline \multirow[t]{4}{*}{ Treatment control } & \multirow{4}{*}{$\begin{array}{l}\text { Penilaian manfaat } \\
\text { pengobatan yang telah } \\
\text { dilakukan }\end{array}$} & Sedikit membantu & 1 & 5 \\
\hline & & Ragu-ragu & 1 & 5 \\
\hline & & Membantu & 10 & 50 \\
\hline & & Sangat membantu & 8 & 40 \\
\hline \multirow[t]{4}{*}{ Identity } & \multirow{4}{*}{$\begin{array}{l}\text { Kemunculan gejala } \\
\text { asmanya }\end{array}$} & Setiap hari & 4 & 20 \\
\hline & & $1-2 x$ seminggu & 8 & 40 \\
\hline & & $1-2 \mathrm{x}$ sebulan & 2 & 10 \\
\hline & & Tidak pernah sama sekali & 6 & 30 \\
\hline \multirow[t]{5}{*}{ Concern } & \multirow{5}{*}{$\begin{array}{l}\text { Kecemasan terhadap } \\
\text { asmanya }\end{array}$} & Sama sekali tidak kuatir & 5 & 25 \\
\hline & & Sedikit kuatir & 5 & 25 \\
\hline & & Ragu-ragu & 1 & 5 \\
\hline & & Kuatir & 6 & 30 \\
\hline & & Sangat kuatir & 3 & 15 \\
\hline \multirow[t]{3}{*}{ Understanding } & \multirow{3}{*}{$\begin{array}{l}\text { Pendapatnya mengenai } \\
\text { pemahaman terhadap } \\
\text { penyakit asma }\end{array}$} & Sangat paham & 3 & 15 \\
\hline & & Paham & 11 & 55 \\
\hline & & Sedikit paham & 6 & 30 \\
\hline \multirow[t]{5}{*}{ Emotional response } & \multirow{5}{*}{$\begin{array}{l}\text { Pengaruh asma terhadap } \\
\text { emosi }\end{array}$} & Tidak membuat emosi & 11 & 55 \\
\hline & & Sedikit emosi & 2 & 10 \\
\hline & & Ragu-ragu & 2 & 10 \\
\hline & & Emosi & 3 & 15 \\
\hline & & Sangat emosi & 2 & 10 \\
\hline
\end{tabular}

aspek personal control dan identity dengan kontrol gejala asma. Penjelasan dari masing-masing aspek sebagai berikut:

a. Consequences (persepsi pasien terhadap akibat/dampak penyakit asma), meliputi dampak dari penyakit. Oleh karena itu dapat dikatakan bahwa terdapat hubungan yang signifikan antara persepsi pasien mengenai dampak dari penyakit dengan kontrol asma. Asma yang tidak terkontrol dapat menyebabkan keterbatasan dalam beraktivitas. Oleh karena itu pada pasien asma lebih disarankan untuk memaha- mi aktifitas-aktifitas apa saja yang dapat memicu timbulnya asma dan membut asmanya tidak terkontrol [2].

b. Timeline (persepsi pasien terhadap lama penyakit asma berlangsung). Dalam penyakit asma tidak mengenal istilah "sembuh", karena penyakit ini tidak dapat disembuhkan dan dapat muncul sewaktu-waktu dan berlangsung selamanya. Oleh karena itu kontrol terhadap penyakit asma tidak berpengaruh terhadap berapa lama penyakit ini akan terus diderita tetapi kontrol asma hanya berpenga- 
Tabel 4. Distribusi frekuensi penyebab asma

\begin{tabular}{llllll}
\hline Penyebab Asma & STS & TS & R & S & SS \\
\hline Stress & 0 & 9 & 0 & 8 & 3 \\
Keturunan/genetik & 1 & 4 & 0 & 9 & 6 \\
Virus/infeksi/kuman & 1 & 12 & 5 & 1 & 1 \\
Pola/kebiasaan makan & 0 & 6 & 1 & 12 & 1 \\
Debu & 0 & 2 & 0 & 12 & 6 \\
Perawatan buruk masa lalu & 0 & 10 & 3 & 7 & 0 \\
Polusi lingkungan & 0 & 1 & 0 & 14 & 5 \\
Perilaku saya sendiri/gaya hidup & 1 & 5 & 1 & 12 & 1 \\
Udara dingin & 0 & 2 & 0 & 14 & 4 \\
Aktifitas fisik & 0 & 1 & 2 & 13 & 4 \\
Terlalu banyak pekerjaan & 0 & 3 & 0 & 15 & 2 \\
Rasa emosional & 0 & 9 & 1 & 9 & 1 \\
Bertambahnya usia & 1 & 8 & 4 & 7 & 0 \\
Konsumsi alkohol & 3 & 7 & 4 & 6 & 0 \\
Merokok & 1 & 4 & 1 & 11 & 3 \\
Akibat cidera/kecelakaan & 3 & 7 & 4 & 6 & 0 \\
Kekebalan tubuh menurun & 0 & 1 & 0 & 16 & 3 \\
Keterangan : & & & & & \\
$\quad$ STS : Sangat tidak setuju & & & & & \\
$\quad$ Tidak setuju & & & & & \\
R : Ragu-ragu & & & & & \\
SS : Sangat setuju & & & & & \\
& & & & & \\
\hline
\end{tabular}

Tabel 5. Distribusi frekuensi 3 faktor yang paling diyakini responden menyebabkan asma

\begin{tabular}{llll}
\hline Faktor yang diyakini sebagai penyebab asma & Pilihan ke-1 & Pilihan ke-2 & Pilihan ke-3 \\
\hline Genetik & 13 & 1 & \\
Merokok & 1 & 1 & 1 \\
Pola makan & 1 & 4 & 2 \\
Polusi & 2 & 8 & 3 \\
Stress & 3 & 1 & 2 \\
Emosional & & 1 & 2 \\
Infeksi/kuman & 1 & 3 \\
Terlalu banyak pekerjaan & 3 & 1 \\
Bertambahnya usia & & 6 \\
Sistem imun tubuh & & & 6 \\
\hline
\end{tabular}

ruh agar penyakit ini tidak sering muncul [2].

c. Personal control merupakan pendapat pasien terhadap kontrol asmanya.

d. Treatment control merupakan pendapat pasien terhadap manfaat pengobatan yang dijalani dalam menunjukkan perbaikan yang dirasakan langsung oleh pasien asma.

e. Identity (persepsi pasien terhadap gejala asma). Pada aspek ini terkait dengan gejala asma, yang menurut Global Initiative for Asth$m a$ [2] bahwa gejala asma yang sering dialami oleh pasien asma adalah timbulnya suara mengi (wheezing sound). Suara mengi ini disebabkan karena adanya gangguan pada saluran nafas atau produksi mucus yang beerlebihan sehingga terjadi kesulitan bernafas sehingga dapat dikatakan semakin sering seseorang mengalami gejala ini maka asmanya semakin 
Tabel 6. Uji hubungan antara aspek dari illness perception dengan kontrol asma

\begin{tabular}{lll}
\hline Aspek dari illness perception & Nilai $\mathbf{P}$ & Kesimpulan \\
\hline Concequences & 0,799 & Tidak ada hubungan signifikan dengan kontrol asma \\
Timeline & 0,341 & Tidak ada hubungan signifikan dengan kontrol asma \\
Personal control & 0,001 & Ada hubungan signifikan dengan kontrol asma \\
Treatment control & 0,174 & Tidak ada hubungan signifikan dengan kontrol asma \\
Identity & 0,004 & Ada hubungan signifikan dengan kontrol asma \\
Concern & 0,599 & Tidak ada hubungan signifikan dengan kontrol asma \\
Emotional response & 0,131 & Tidak ada hubungan signifikan dengan kontrol asma \\
Understanding & 0,604 & Tidak ada hubungan signifikan dengan kontrol asma \\
\hline
\end{tabular}

Keterangan:

Bila nilai $\mathrm{P}<0,05$ berarti ada hubungan signifikan antara aspek illness perception dengan kontrol asma

tidak terkontrol. Hal ini mungkin disebabkan oleh kurangnya pemahaman pasien tentang asma [13], termasuk mengenali gejala asma yang dapat muncul.

f. Concern, membahas mengenai kecemasan pasien terhadap penyakit asma yang dideritanya.

g. Emotional response terkait perubahan emosi akibat pengaruh asma yang dialaminya.

h. Understanding mengenai pendapat pasien asma terhadap seberapa besar pemahamannya terhadap penyakitnya.

Meskipun pengobatan yang efektif telah dilakukan untuk menurunkan morbiditas karena asma, namun keefektifan terapi akan tercapai jika telah terjadi kesesuaian dalam penggunaan obat. Selain itu, persepsi pasien juga berperan penting dalam keberhasilan terapi, karena persepsi pada diri masing-masing individu mengakibatkan respon individu yang berbeda antara satu individu dengan individu yang lain. Oleh karena itu, selain faktor kesesuaian obat yang digunakan kita juga harus memperhatikan persepsi dari dalam diri pasien itu sendiri [1].

\section{Kesimpulan}

Berdasarkan penelitian yang telah dilakukan, maka dapat disimpulkan bahwa sebagian besar gejala asma responden terkontrol dengan baik (65\%). Hubungan antara gejala asma dengan ill- ness perception menunjukkan bahwa ada hubungan yang signifikan antara kontrol asma dengan hanya dua aspek illness perception yaitu personal control dan identity, sedangkan aspek yang lain tidak. Oleh karena itu perlu dilakukan penelitian lebih lanjut mengenai pengaruh persepsi sakit dan kontrol penyakit terhadap kualitas hidup responden untuk melihat apakah responden yang memiliki persepsi sakit dan kontrol yang baik juga akan memiliki kualitas hidup yang baik pula. Penelitian lebih lanjut mengenai hubungan persepsi sakit dan kontrol penyakit pada lingkungan dan tempat yang berbeda dengan karakteristik sampel penelitian yang berbeda juga perlu dilakukan.

\section{Daftar pustaka}

1. Departemen Kesehatan RI. Pharmaceutical Care untuk Penyakit Asma. Jakarta: Bakti Husada; 2007.

2. Global Initiative for Asthma. Global strategy for asthma management \& prevention (update). 2015.

3. Harding G, Taylor K. Social dimensions of pharmacy:(4) Health, illness and seeking health care. Pharmaceutical Journal. 2002;12(269):526-8.

4. Dinwiddie R, Muller WG. Adolescent treatment compliance in asthma. J R Soc Med. 2002;95(2):68-71.

5. Cochrane GM, Horme R, Chanez P. Compliance in asthma. Respiratory Medicine. 1999;93(11):763-9.

6. Horne R, Price D, Cleland J, Costa R, Covey D, Gruff- 
ydd-Jones $\mathrm{K}$, et al. Can asthma control be improved by understanding the patient's perspective? BMC Pulmonary Medicine. 2007;7(1):1.

7. Petrie K, Weinman J. Why illness perceptions matter. Clinical Medicine. 2006;6(6):536-9.

8. Lorensia A, Lisiska N. Illness perceptions study of asthma treatment compliance in pharmaceutical care. ANIMA. 2011;26(3):184-8.

9. Broadbent E, Petrie KJ, Main J, Weinman J. The brief illness perception questionnaire. Journal of psychosomatic research. 2006;60(6):631-7.

10. Van Ittersum M, Van Wilgen C, Hilberdink W, Groo- thoff J, Van der Schans C. Illness perceptions in patients with fibromyalgia. Patient Education and Counseling. 2009;74(1):53-60.

11. Moss-Morris R, Weinman J, Petrie K, Horne R, Cameron L, Buick D. The revised illness perception questionnaire (IPQ-R). Psychology and health. 2002;17(1):1-16.

12. Lemeshow S. Besar Sampel dalam Penelitian Kesehatan. Yogyakarta: Gajah Mada University Press; 1997, p. 55.

13. Marieb N. Esssentials of human anatomy and physiology, $4^{\text {th }}$ ed. United States; 2004. 